
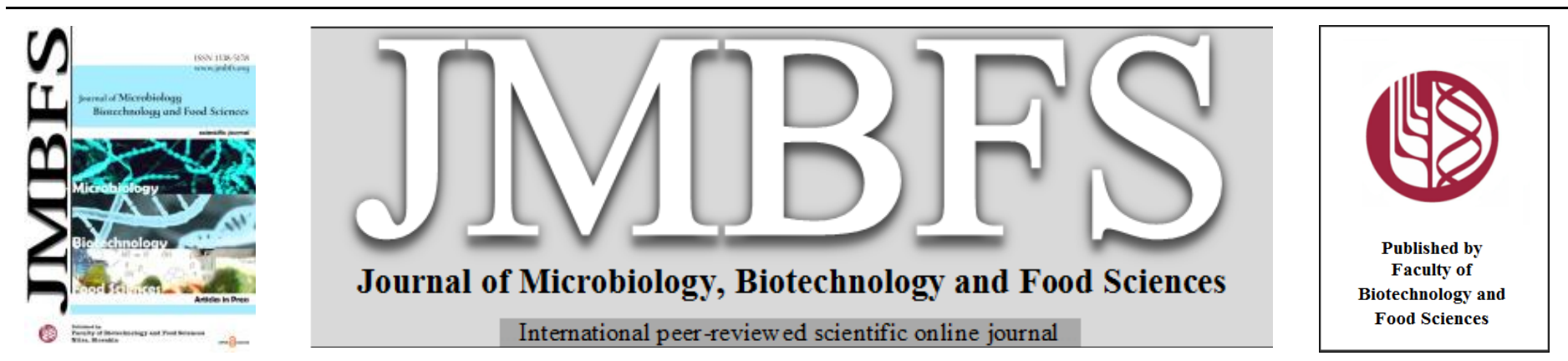

\title{
ENHANCING THE ANTIBACTERIAL EFFECT OF BACTERIOCIN FROM LACTOCOCCUS LACTIS SUBSP. LACTIS USING CHITOSAN NANOPARTICLES
}

\author{
Emad Atef Helmy Guirguis* \\ $\operatorname{Address}(e s)$ : \\ ${ }^{1}$ Department of Food Hygiene, National Nutrition Institute (NNI), General Organization of Teaching Hospitals and Institutes (GOTHI), Cairo, Egypt. Mob.: \\ +201225132595 .
}

*Corresponding author: $\mathrm{dr}$ emad_atef@yahoo.com

https://doi.org/10.15414/jmbfs.3777

\section{ARTICLE INFO}

Received 1. 10. 2020

Revised 8. 6. 2021

Accepted 16. 6. 2021

Published 1. 12. 2021

Regular article OPEN $\partial_{\text {ACCESS }}$

\begin{abstract}
Chitosan, a cationic polymer derived from the hot alkali deacetylation of chitin, has numerous biological applications with non-toxicity, biocompatibility and biodegradability. Chitosan nanoparticles were prepared and encapsulated with bacteriocin extracted from Lactococcus lactis subsp lactis to produce chitosan nanoparticles conjugate bacteriocin using ionic gelation method. This formulation was examined for its antibacterial activity representing food bio-preservative against Salmonella typhimurium, Escherichiae coli, Bacillus cereus and Staphylococcus aureus, compared with chitosan nanoparticles, crud chitosan and free bacteriocin. Agar diffusion method was applied to evaluate the in-vitro drug release, effect of $\mathrm{pH}$ and temperature on its stability. The results revealed that the Invitro release within 24 hours of chitosan nanoparticles conjugate bacteriocin was controlled by about $(79 \%)$ with cumulative and sustained effect when compared with free bacteriocin (94\%). Chitosan nanoparticles conjugate bacteriocin exhibit the highest antibacterial activity (with significant difference $\mathrm{p}<0.05$ ) followed by free bacteriocin and chitosan nanoparticles, while crud chitosan was the lowest representing thermal stability $\left(\leq 70^{\circ} \mathrm{C}\right)$ when subjected to low $\mathrm{pH}$. Gram-positive bacteria were more susceptible than Gram-negative bacteria to all of the components. Chitosan nanoparticles contribute successful safe food preservative enhancement when incorporated with bacteriocin against the common food-borne pathogenic bacteria.
\end{abstract}

Keywords: Bacteriocin, Chitosan nanoparticles, Nanoparticles conjugate bacteriocin

\section{INTRODUCTION}

Chitosan is a non-toxic biodegradable copolymer consists of D-glucoseamine and $\mathrm{N}$-acetyle-D-glucoseamine units from chitin deacetylation in the presence of hot alkali (Zaghloul et al., 2015). It contains amino, primary and secondary hydroxyl as relative function groups in $\mathrm{C} 2, \mathrm{C} 3$ and $\mathrm{C} 6$ positions, respectively (Ali and Toliba, 2018). Ionic gelation method with tripolyphosphate (TPP) ion was investigated by Kahdestani $\boldsymbol{e t}$ al. (2021) to prepare chitosan nanoparticles (CSNps) from crude chitosan.

Chitosan reveal antimicrobial activity against many spoilage and pathogenic microorganisms representing Gram-positive and Gram-negative bacteria, molds and yeasts. Its antimicrobial effect is depending on the deacetylation degree, type of microorganism, molecular weight and $\mathrm{pH}$ value (Eldaly et al., 2018). The antimicrobial properties of CSNps and its derivatives were proven in previous literature studies (Acay et al., 2020). It encapsulates bioactive formulations in micro or nanoparticles form in addition to its antimicrobial properties (CorreaPacheco et al., 2018). The low toxic and ecological safe biocompatibility and admirable biodegradability with antimicrobial activity provided ample opportunities for further applications (Chawla et al., 2014). CSNps are effective for sustained bioactive release because it mitigates the bioactive release (Kahdestani et al., 2021).

Lactic acid bacteria (LAB), commonly used in food preservation, exhibit antagonistic activity and inhibiting pathogenic and spoilage microbiota in food and food products via bacteriocins and other metabolites which have vital antimicrobial capacities (Akbar et al., 2019).

Bacteriocins, antimicrobial peptides synthesized by ribosomes, display bacteriostatic or bacteriocidal effect toward target specificity closely related and/or broad range bacterial strains (Abdelsamei et al., 2015; Woraprayote $\boldsymbol{e t}$ al., 2016). These bacteriocins have small cationic molecules containing 30 to 60 amino acids which form amphiphilic helices, have heat stability when subjected to temperature of $100^{\circ} \mathrm{C}$ for $10 \mathrm{~min}$ and differ from each other in mode of action, spectrum of activity, biochemical properties, genetic origin and molecular weight (Mokoena, 2017).

Among bacteriocinogenic LAB, Lactococcus spp produced bacteriocins (Yusuf and Abdul Hamid, 2013). Lactococcus lactis generally isolated from fermented raw milk and known as Generally Recognized As Safe (GRAS) strain. This strain prevents pathogenic bacterial growth in the fermented products by converting lactose to lactic acid as a result of its proteolytic activity. The produced lactic acid considers an important role in the final taste and texture of fermented products (Tenea and Suárez, 2020)

The most common bacteriocin produced by Lc. lactis is nisin A and its variants. It represents Class I bacteriocin, Ripps, post-translationally modified peptides, heat stable, lanthionine and methyllanthionine containing peptides $(<5 \mathrm{KDa})$ with members consisting lacticins (Meade $\boldsymbol{e t}$ al., 2020). Whereas, LAB produce one bacteriocin, L. lactis produce 2 synergistically Class II bacteriocins named LsbA and LsbB (Duhan et al., 2013). Bacteriocins inhibit only Gram-positive bacteria including Staphylococcus aureus and Listeria monocytogenes because Gram negative bacteria exhibit high resistance to these compounds (Moreno et al., 2000).

Where bacteriocins exploitation to be applied as preservatives showing slow pace moving is yet to be addressed for various limitations, bacteriocin-nanoconjugates utilization in food industry are basically focused to overcome the challenges of using bacteriocins alone. To combat the direct addition of bacteriocin and its susceptibility to storage conditions, changes in temperatures and production process, nanoparticles provides an efficient technology to protect and deliver their potential antibacterial effect (Sidhu and Nehra, 2019).

Nanoparticles are known as particles with dimensions ranged from 1 to $100 \mathrm{~nm}$ with unique properties thanks to the reduction of its dimension to the atomic level increasing the atomic surface compared to the bulk equivalents (Divya and Jisha, 2018). The suitable formulation technique using nanoparticles (nanoencapsulation) improve the antimicrobial activity of bacteriocins (Namasivayam et al., 2015). These nanoparticles have the potential to diffuse and cross-biological cellular membrane barrier of different cell type. Several studies have modified chitosan as biocompatible nontoxic polymer with integrated ability to antimicrobial peptides to form chitosan-based nanoparticles vehicle for delivery applications (Tamara et al., 2018; Kahdestani et al., 2021). The aim of the present study is to evaluate the potential release and stability of bacteriocin encapsulated with CSNps under different values $\mathrm{pH}$ and temperatures and as well as its antibacterial activity against common food-borne pathogenic bacteria. 


\section{MATERIALS AND METHODS}

\section{Bacterial strains}

Lyophilized strains of bacteriocin producing bacteria and food-borne pathogenic bacteria were obtained from different cultures collections as shown in (Table, 1).

Table 1 Source of bacterial strains.

\begin{tabular}{|c|c|c|}
\hline Bacterial strains & $\begin{array}{c}\text { Strain } \\
\text { number/identification }\end{array}$ & Sources \\
\hline \multicolumn{3}{|c|}{ Bacteriocin producing bacteria } \\
\hline $\begin{array}{l}\text { Lactococcus lactis subsp } \\
\text { lactis }\end{array}$ & $\mathrm{EMCC}^{\mathrm{a}} 11552$ & $\begin{array}{l}\text { Dairy Department, } \\
\text { Minia University }\end{array}$ \\
\hline \multicolumn{3}{|c|}{ Food-borne pathogenic bacteria } \\
\hline Salmonella typhimurium & ATCC $^{\mathrm{b}} 14028$ & Cairo MIRCEN $^{\mathrm{c}}$ \\
\hline Escherichiae coli & ATCC $^{\mathrm{b}} 10536$ & Cairo MIRCEN $^{\mathrm{c}}$ \\
\hline Bacillus cereus & ATCC $^{\mathrm{b}} 10876$ & Cairo MIRCEN $^{\mathrm{c}}$ \\
\hline Staphylococcus aureus & ATCC $^{\mathrm{b}} 6538$ & Cairo MIRCEN $^{\mathrm{c}}$ \\
\hline
\end{tabular}

a) EMCC: Egyptian Microbial Culture Collection.

b) ATCC: American Type Culture Collection.

c) Cairo MIRCEN: Cairo Microbiological Resources Center, Faculty of Agriculture, Ain Shams University.

\section{Bacterial activation}

Different bacterial strains: bacteriocin producing bacteria and food-borne pathogenic bacteria, were activated at $37{ }^{\circ} \mathrm{C}$ for $24 \mathrm{~h}$ using MRS (De Man, Rogosa and Sharpe) broth CM0359 and Nutrient broth CM0001 media from Oxoid UK, respectively. In order to meet the active recommended levels, bacterial cultures were adjusted with sterile saline to McFarland standard $\left(1.5 \times 10^{8} \mathrm{cfu} / \mathrm{ml}\right)$ (Abdelsamei et al., 2015).

\section{Extraction of free bacteriocin (free-B)}

According to Mostafa et al. (2019), free bacteriocin (free B) was extracted by incubation of active Lc. lactis subsp. lactis culture was inoculated into $250 \mathrm{ml}$ of MRS broth $(1 \% \mathrm{v} / \mathrm{v})$, incubated at $37^{\circ} \mathrm{C}$ for $18 \mathrm{~h}$ and then centrifuged (Centrifuge $\mathrm{K} 2015$, Centurion Scientific, UK) at $10,000 \mathrm{rpm}$ for $10 \mathrm{~min}$ at $4^{\circ} \mathrm{C}$. The supernatant contained crude bacteriocin was subjected to salt saturation method to be partially purified by adding $70 \%$ saturation ammonium sulphate during a magnetic stirring (AccuPlate, Labnet, USA) at $4^{\circ} \mathrm{C}$ then centrifuged at 10,000 $\mathrm{rpm}$ for $20 \mathrm{~min}$ at $4^{\circ} \mathrm{C}$ to separate the precipitated proteins. The final protein pellet was dissolved in Phosphate-buffered saline (PBS) at pH 7.0 (Code: S3024, Agilent, USA) then sterilized through Seitz filter (Millipore, USA) with $0.22 \mu \mathrm{m}$ pore size filter.

\section{Preparation of Chitosan nanoparticles (CSNps)}

Ionic gelation method was performed by dissolving $0.2 \mathrm{~g}$ of chitosan (deacetylation degree of $93 \%$ from Sigma-Aldrich, USA.) was dissolved in 100 $\mathrm{ml}$ of $1 \%$ acetic acid, drop wise of sodium tripolyphosphate (TPP from SigmaAldrich, USA.) added during stirring for $3 \mathrm{~h}$ and subsequently centrifuged at 10,000 rpm for $10 \mathrm{~min}$ to obtain pellet contain CSNps (Divya et al., 2017).

\section{Preparation of Chitosan nanoparticles conjugate bacteriocin (CSNps-B)}

To prepare chitosan incorporated bacteriocin, the above mentioned ionic gelation method was implemented with mixing $10 \mathrm{ml}$ of free-B suspension after adding the $1 \%$ acetic acid. The centrifuged step (at 10,000 rpm/10 min) resulted in pellet contain CSNps-B (Namasivayam et al., 2015).

\section{In-vitro release of bacteriocin}

To determine in-vitro bacteriocin release, dialysis bag method was used according to Bohrey et al. (2016) with modifications. An amount of $5 \mathrm{ml}$ of release medium (0.1M PBS with $\mathrm{pH} 7.4$ ) contained $50 \mathrm{mg}$ of CSNps-B or free-B was pipette in dialysis bag at $37^{\circ} \mathrm{C}$, then placed in beaker contained $100 \mathrm{ml}$ of PBS. The beaker was placed over magnetic stirrer at $100 \mathrm{rpm} / 37 \pm 1{ }^{\circ} \mathrm{C}$. An intermittent bacteriocin release was assessed by withdraw $2 \mathrm{ml}$ samples at 1, 2, 3, ..., up to $24 \mathrm{hrs}$ while replacement with an equal amount with PBS. Samples were examined for bacteriocin release percent using US-Vis spectrophotometer (Jenway 6105, USA) at $291 \mathrm{~nm}$.

\section{Preparation of different formulations}

Under aseptic conditions three-fold tubes $(12 * 75 \mathrm{~mm})$ representing 4 groups include crud chitosan, CSNps, free-B or CSNps-B were accurately quantified then added to $0.25 \%$ acetic acid to prepare $100 \mu \mathrm{g} / \mathrm{ml}$ concentration according to Abdeltawab et al. (2019).

\section{Assessments and characterizations}

\section{In-vitro release of bacteriocin}

To determine in-vitro bacteriocin release, dialysis bag method was used according to Bohrey et al. (2016) with slight modifications. $5 \mathrm{ml}$ of release medium (0.1M PBS, pH 7.4) containing $50 \mathrm{mg}$ of CSNps-B or free-B was pipette in dialysis bag at $37^{\circ} \mathrm{C}$, then placed in beaker containing $100 \mathrm{ml}$ of PBS. The beaker was stirred at $37 \pm 1^{\circ} \mathrm{C}$ using a magnetic stirrer at $100 \mathrm{rpm}$. An intermittent bacteriocin release was assessed by withdrawing $2 \mathrm{ml}$ samples each hour for 24 hrs, with one hour as interval time, with replacing an equal amount of PBS. Samples were examined for the percentage of bacteriocin release using US-Vis spectrophotometer (Jenway 6105, USA) at $291 \mathrm{~nm}$.

\section{Antibacterial activity assay}

Agar well diffusion method was applied to evaluate the food-borne pathogenic bacterial response against the formulation groups, by measuring the inhibition zone in millimeters $(\mathrm{mm})$. Sterile cork borer well made wells by removing slug from inoculated Mueller Hinton Agar (Code: 64884, BIO-RAD, USA). The individual bacterial cultures were loaded with $100 \mu \mathrm{l}$ of the separated treatments and then incubated at $37^{\circ} \mathrm{C}$ for $24 \mathrm{~h}$. The measurements were carried out in triplicates (Balouiri et al., 2016).

\section{Stability at different $\mathrm{pH}$ values}

To assess the effect of $\mathrm{pH}$ on the prepared formulation groups, tubes containing 5 $\mathrm{ml}$ of the concentrates were $\mathrm{pH}$ adjusted at different values of $\mathrm{pH}$ which ranged from 4 to 11 with sterile lactic acid $(1 \% \mathrm{w} / \mathrm{v})$ or $\mathrm{NaOH}(1 \mathrm{M})$ at room temperature $\left(22^{\circ} \mathrm{C}\right)$ for 2 hours then readjusted to 7 as $\mathrm{pH}$ value. The antibacterial activity of these concentrates was determined using agar well diffusion method (Mostafa et al., 2015).

\section{Stability at different heating treatments}

Tubes containing $5 \mathrm{ml}$ of the above mentioned concentrates were over covered with paraffin oil to avoid evaporation, separately incubated in water bath (Memmert, WB14, Germany) for $30 \mathrm{~min}$ at different temperatures varied from 0 to $100 \mathrm{C}$ with interval $10^{\circ} \mathrm{C}$ and then cooled immediately at $4^{\circ} \mathrm{C}$. Concentrates were determined for antibacterial activity by agar well diffusion method (Mostafa et al., 2019).

\section{Statistical analysis}

The obtained results representing the data of duplicated experiments were statistically analyzed. Analysis of variance among formulations and treatments were performed by entering data through one-way ANOVA and paired-samples T-test using (IBM-SPSS, 20; USA) with statistical significance declared at $\mathrm{p}<$ 0.05 (Rabie et al., 2015).

\section{RESULTS AND DISCUSSION}

\section{In-vitro release of bacteriocin}

The efficiency of loaded CSNps with bacteriocin produced by Lc. lactis subsp lactis as safe food preservative was in vitro evaluated by comparing formulations, i.e. CSNps-B and its components (chitosan, CSNps and free-B), against Gram positive and Gram negative food-borne pathogenic bacteria.

The release behavior of bacteriocin from CSNps-B and free-B during 24 hours was carried out using dialysis bag method and shown in Figure (1). Gradual increase of bacteriocin release was found to be 79 and $95 \%$ from CSNps-B and free-B tubes, respectively. During the initial 4 hours, burst release about $83 \%$ of bacteriocin from free-B tubes then slightly increase to release about $94 \%$ by the end of 24 hours. On the other hand, cumulative sustained release from tubes containing CSNps-B was observed reaching about $28 \%$ within 4 hours and $79 \%$ by the end of 24 hours. A significant difference at $p<0.05$ was observed when compared with the paired-samples T-test. 


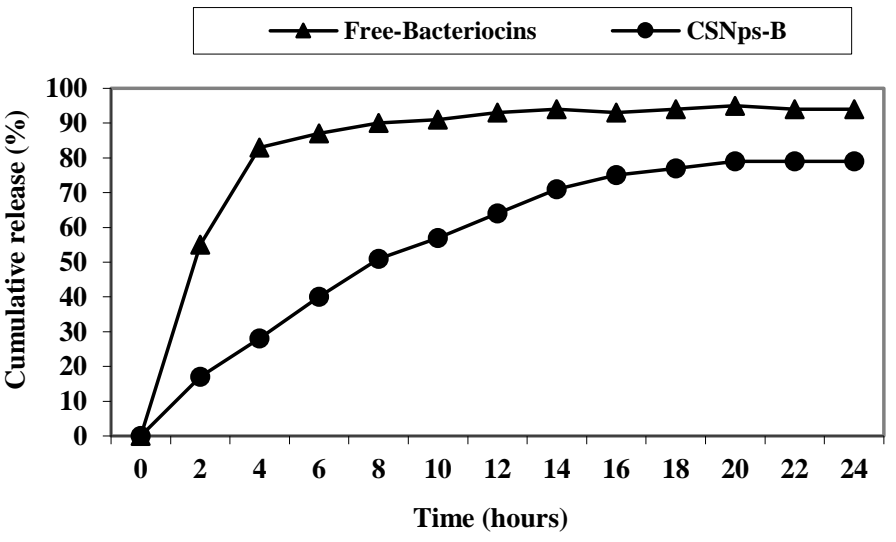

Figure 1 In vitro profile of bacteriocin release. ${ }^{*}$ Significant difference $(p<0.05)$ was observed.

The obtained results are in agreement with those reported by Namasivayam $\boldsymbol{e t}$ al. (2015) and Bohrey et al. (2016). The bacteriocins are contained within or covalently linked to CSNps, attained a high free-B concentrate, resulting in lower release over the time with a better efficacy of comparable doses which exploited for preventing bacterial growth (Teixeira et al., 2020). Chitosan encapsulated active compound increases their control release and protect its components against environmental factors (Alishahi, 2014). So, CSNps-B could be used to control bacteriocin release to improve its bioavailability (Singh et al., 2018).

\section{Antibacterial activity}

In order to investigate the efficiency of impregnate CSNps with bacteriocin produced from Lc. lactis subsp. lactis, 4 formulations were prepared including CSNps-B, CSNps, chitosan and free-B were examined for their antibacterial activity against food-borne pathogenic bacteria. The bio-preservation effect of these formulations against Gram-positive $\left(\mathrm{G}^{+}\right)($B. cereus and Staph. aureus) and Gram-negative $\left(\mathrm{G}^{-}\right)$bacteria (E. coli and $S$. typhimurium) by agar well diffusion method was illustrated in Figure (2). The results revealed that Gram-negative bacteria were more resistant than Gram-positive ones toward the 4 formulations. According to Prudêncio et al. (2015), the outer membrane of Gram-negative bacteria may act as an effective barrier protecting it against Gram-positive bacterial bacteriocins. The meticulous nature of cellular envelope of Gramnegative bacteria could resist the bacteriocins throughout the adsorption phenomena (Goraya et al., 2013).

The measured inhibition zone $(\mathrm{mm})$ indicates that all of the bacteria showed high sensitivity against CSNps-B with inhibition zones ranged from 20 to $23 \mathrm{~mm}$ for gram-positive bacteria and from 14 to $16 \mathrm{~mm}$ for Gram-negative bacteria. A significant difference $(p<0.05)$ was observed when the inhibition zone obtained by CSNps-B was compared with those obtained by the other 3 formulations: chitosan (6 to 8), CSNps (8 to 10) and Free-B (6 to 14$)$.

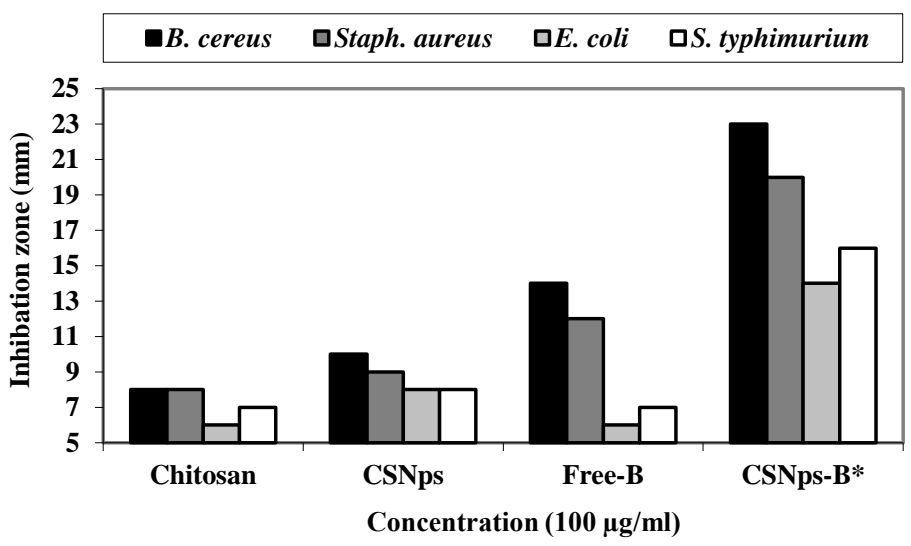

Figure 2 Inhibition zone (mm) of chitosan, CSNps, free-B and CSNps-B agains food-borne pathogenic bacteria. * Significant difference $(p<0.05)$ between CSNps-B and the other formulations was observed.

Bacteriocins produced by Lc. lactis subsp. lactis may contains lantibiotic nisin-A which in turn binds lipid II, inhibiting the synthesis of peptidoglycan and forming a complex of membrane pore (Kim et al., 2020). This exhibits different action mechanisms including the interaction with cell wall, cell membrane and intracellular organelles in addition to binding the genetic material. With prokaryotic selectivity, it adheres to bacterial cells and penetrates phospholipids membranes as a result of cationic small size and alteration of hydrophobic, hydrophilic and charge properties (Meade et al., 2020).

Furthermore, bacteriocins bind to charged phospholipids headgroups and proteinaceous receptors in the bacterial cell membrane resulting in pores formation within the cytoplasmic membrane and depletion the proton motive force leading to interfere with cell biosynthesis and further cell death (Abamecha, 2017).

Chitosan had an antibacterial activity thanks of the positive charges which interact with plasma membrane phospholipids (negative charges) causing leakage of components then cell death by altering the cell permeability, chelating property of metal ions, and inhibiting the mRNA synthesis by penetrating the cell wall and binding to the DNA (Divya and Jisha, 2018).

The obtained results are in concurrence with that reported by Divya et al. (2017) who found that CSNps exhibited large inhibition zone for all microorganisms, i.e. Klebsiella pneumonia, E. coli, Staph. aureus and Pseudomonas aeruginosa, with superior antimicrobial activity when compared with chitosan. These results could be explained by the fact that CSNps could diffuse better than chitosan and cross the cell membrane as biological barrier (Kahdestani et al., 2021). The increase in the antibacterial activity using these nanoparticles may be due to the compactable arrangement and strong interaction of smaller particle size increase its surface to volume ratio (Divya et al., 2017; Acay et al., 2020).

The combination of nanoparticles and loaded active compounds may exert a synergistic effect as nanoparticles themselves have antibacterial activity. The modified nanoparticles with target active molecules could attack the specific biological sites (Teixeira et al., 2020). CSNps-B could provide nanoencapsulation which in turn protects bacteriocins from the degradation by proteolytic enzymes degradation rendering bioactive component stability and increase the shelf life of food (Sidhu and Nehra, 2019). In food, nisin as a free bacteriocin is exhausted due to its interaction with lipids, proteins, enzymatic degradation and uneven distribution within food matrix. Encapsulation of bacteriocin with CSNps has a synergistic demonstrated antibacterial effect against bacterial growth rather than its individual components (Alishahi, 2014) CSNps may cause morphological changes such as formation of pores in Grampositive and Gram-negative bacterial cell membrane which in turn facilitate the bacteriocin cell penetration (Pan et al. 2011). Several studies reported that bacteriocin conjugated with nanoparticles enhanced and increased the antibacterial activity against food borne pathogenic bacteria by about two to four times more higher than the use of bacteriocin alone (Zohri et al., 2010; Zohri et al., 2013).

\section{Effect of pH on the antibacterial activity}

Environmental parameters such as $\mathrm{pH}$ and temperature were investigated to define the optimized conditions in order to maximize the antibacterial activity. Figure (3) shows the effect of different $\mathrm{pH}$ values on the antibacterial activity of the 4 formulations (chitosan, CSNps, free-B and CSNps-B), on the growth of food borne pathogenic bacteria; B. cereus, Staph. aureus, E. coli, and $S$. typhimurium. An increase in inhibition zone was observed at lower $\mathrm{pH}$ values using the different formulations for all studied strains wherein the highest inhibition zone was recorded at $\mathrm{pH}=4$. Whereas, a gradual decrease trend in inhibition zone was found with increasing the $\mathrm{pH}$ value wherein the lowest inhibition zone was observed at $\mathrm{pH}=11$. The release of bacteriocin (nisin) is $\mathrm{pH}$ depending; Wu et al. (2016) found higher significant release of bacteriocin (nisin) at $\mathrm{pH}$ value of 3 (with $46 \%$ cumulative bacteriocin during $72 \mathrm{hrs}$ ) than those at 6 as $\mathrm{pH}$ value.

It was found that CSNps-B exhibited the highest antibacterial activity for all bacterial strains followed by free-B, CSNps, and chitosan at different $\mathrm{pH}$ values. Furthermore, CSNps and chitosan did not exhibit any antibacterial activity at $\mathrm{pH}$ values of 10 and 11 against both $B$. cereus and Staph. aureus.

It is worth to mention here that at $\mathrm{pH}$ value of 10; only the CSNps-B exhibited an antibacterial activity on the growth of $E$. coli and S. typhimurium while, no effect was observed at $\mathrm{pH}$ value of 11 . Moreover, the Gram-negative bacteria; E. coli and $S$. typhimurium, were more resistant to all formulations compared to Grampositive bacteria; B. cereus and Staph. aureus.

The obtained results are in agreement with those reported by Adesina and Enerijiofi (2016) and Kumari et al. (2018) who reported that the most active bacteriocin against bacterial indicators was in $\mathrm{pH}$ values ranged from 6 to 7 with slight sensitivity at $\mathrm{pH}=7$, while a decrease in antibacterial activity was observed at $\mathrm{pH}$ values varied from 2 to 5 . 

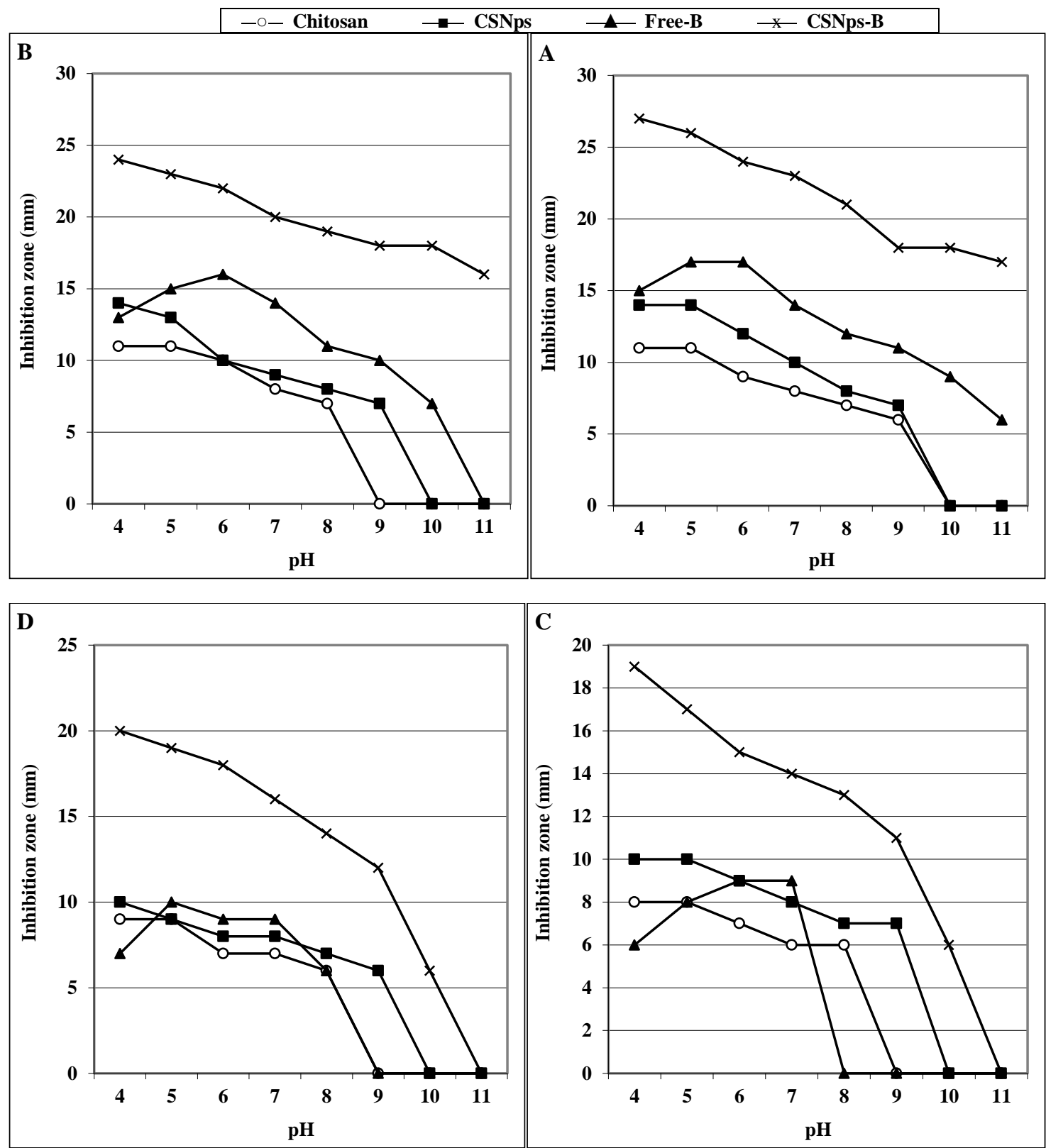

Figure 3 Stability of chitosan, CSNps, Free-B and CSNps-B at different pH against food-borne pathogenic bacteria: A) B. cereus, B) Staph. aureus, C) E. coli and D) S. typhimurium. [* Significant difference $(\mathrm{p}<0.05)$ between CSNps-B and the other formulations was observed.]

In contrast, Zacharof and Lovitt (2012) showed that bacteriocins produced from LAB had high antibacterial activity at $\mathrm{pH}$ values below 5 .

Similar results concerning the antibacterial activity of chitosan were obtained by

Qi et al. (2004) who reported a high antibacterial activity of chitosan only in acidic medium, as it loses its solubility at $\mathrm{pH}$ value higher than 6.5 . A complete loss of bacteriocin activity especially nisin was also observed by Benkerroum $\boldsymbol{e}$ al. (2002) at neutral $\mathrm{pH}$ as a result of decreasing its solubility Furthermore, the free amino groups in the d-glucosamine units may result in its protonation (Kahdestani et al., 2021). The obtained results are in disagreement with those found by Alishahi, (2014) who reported that the release of bacteriocin was faster at higher $\mathrm{pH}$ than that at the lower $\mathrm{pH}$ wherein the diffusion process controlled the release of bacteriocin at acidic environment.

The high antibacterial effect of CSNps compared to chitosan may be due to the interfacial interaction between CSNps small particle size and the bacterial cell membrane throughout the endocytosis (Divya and Jisha, 2018; Lee et al., 2018). The high bacteriocin release at lower $\mathrm{pH}$ values may be due to the dissolution and swelling of CSNps (Khan et al., 2020). Bacteriocins exhibited high activity at $\mathrm{pH} 2-5$ however, a loss by about $5.9-10 \%$ of its activity was observed at alkaline levels (Abanoz and Kunduhoglu, 2018; Kaktcham et al., 2019). While, the antibacterial activity of chitosan may be due to the interactions between the positive charged amino groups and the negative charged bacterial membrane (Kravanja et al., 2019).

The obtained results could be explained by 1) changes in the molecular interactions which take place between biopolymers as a result of the variation in $\mathrm{pH}$ values (Wu et al., 2016); 2) increasing the positive charges of chitosan as a result of lowering $\mathrm{pH}$ value which in turn increases its affinity towards the bacterial cell wall; increased protonated amino groups such as - $\mathrm{NH} 3$ groups with positive charges can bind to bacterial membrane components with negative charges. Moreover, the antibacterial activity at $\mathrm{pH}$ values below 6 may be due to the consequent of positively charged protonation which interacts with teichoic acid in Gram-positive bacteria and anionic lipopolysaccharides in Gram-negative bacteria (Malinowska-Pañczyk et al., 2015), and 3) alteration of mRNA functions and limiting the interactions of DNA through their binding with the low molecular weight which can pass through the cell (Rizeq et al., 2019).

\section{Effect of temperature on the antibacterial activity}

In order to investigate the heating effect on the antibacterial activity of the 4 formulations expressed by the inhibition zone using different temperatures which varied from 0 to $100^{\circ} \mathrm{C}$ for $30 \mathrm{~min}$. Figure (4) shows that the 4 formulations exhibited different heat stability representing different antimicrobial activity against Gram-positive and Gram-negative bacteria. The highest stability was recorded for temperatures ranged from 0 to $70^{\circ} \mathrm{C}$. Beyond these temperatures, a gradual decrease trend was observed until the absence of inhibition zone except CSNps-B at $100^{\circ} \mathrm{C}$. The highest inhibition zone was observed for CSNps-B ( $\mathrm{p}<$ 0.05 ) followed by free-B, CSNps, and chitosan. CSNps-B showed higher antibacterial activity against Gram-positive more than Gram-negative bacteria. The obtained results are in agreement with those reported by Azhar et al. (2017), Le et al. (2019) and Mostafa et al. (2019). The combined use of CSNps-B with high temperature may provide synergistic effect which includes the effect of high 
temperature and the antibacterial activity of CSNps-B increasing the inhibition zone which reflects the growth inhibition of food-borne bacteria (Prudêncio $\boldsymbol{e}$ al., 2015). Therefore, the heat stability of CSNps-B, Free-bacteriocin, CSNps and chitosan allows their applications as food preservative under the mentioned conditions of temperatures.
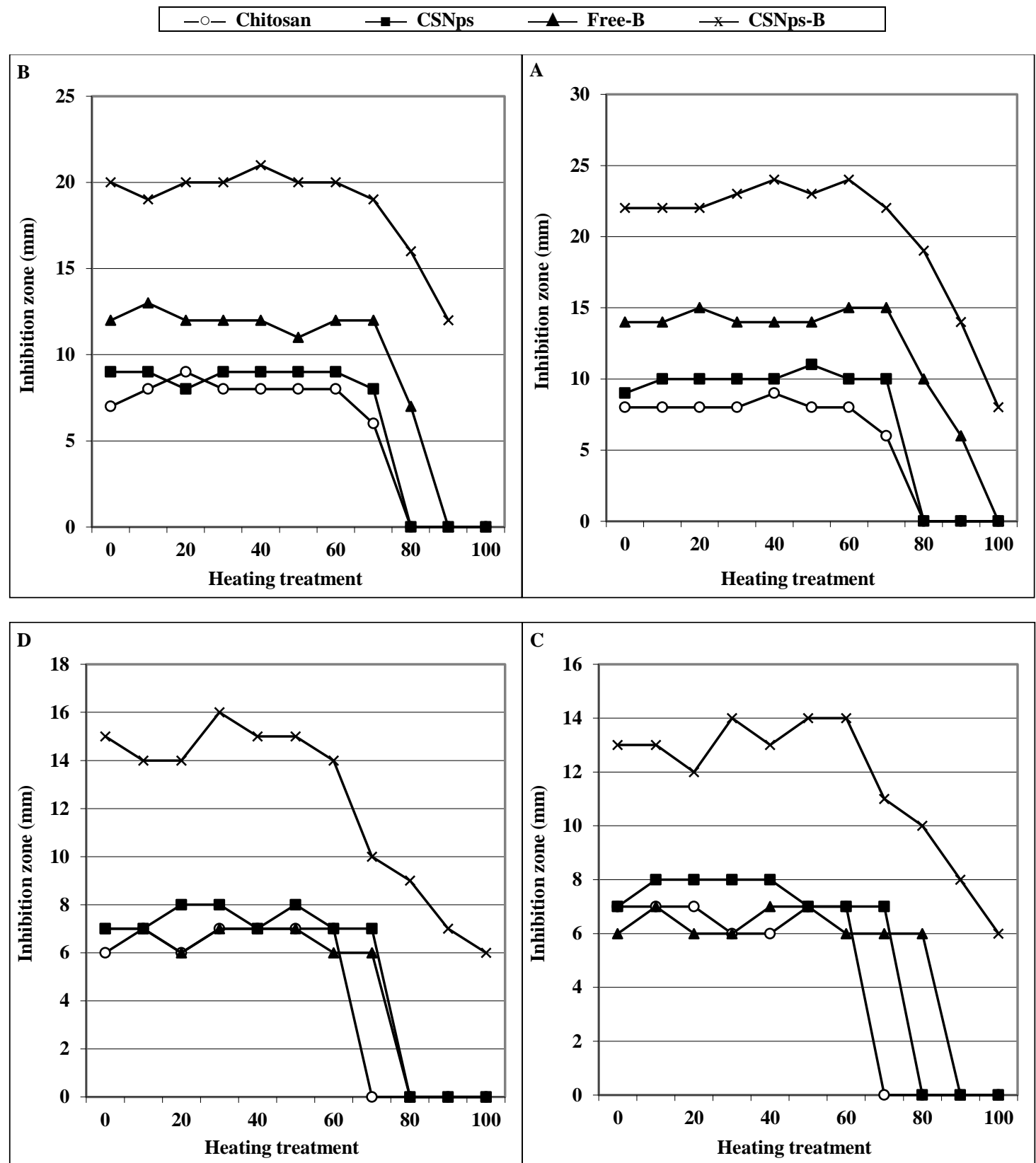

Figure 4 Stability of chitosan, CSNps, Free-B and CSNps-B at different heating treatment against food-borne pathogenic bacteria: A) B. cereus, B) Staph. aureus, C) E. coli and D) S. typhimurium. [* Significant difference $(\mathrm{p}<0.05)$ between CSNps-B and the other formulations was observed.]

\section{CONCLUSION}

The combination of bacteriocins with CSNps (CSNps-B) increased the antibacterial activity of bacteriocin as food preservative extending the shelf life of food without altering its quality attributes. CSNps-B showed high antibacterial activity at wide range of temperature and $\mathrm{pH}$. It exhibited higher antibacterial activity against Gram-positive pathogenic bacteria which was observed at lower values of $\mathrm{pH}$ than Gram-negative pathogenic bacteria. So, CSNps-B could be used as food bio-preservative inhibiting the growth of food-borne bacteria.

\section{REFERENCES}

Abamecha, A. (2017). The role of bacteriocins in the controlling of foodborne pathogens. Indo American Journal of Pharmaceutical Research, 7 (1): 7598-7605 http://doi.org/10.5281/zenodo.2382309

Abanoz, H.S. \& Kunduhoglu, B. (2018). Antimicrobial Activity of a Bacteriocin Produced by Enterococcus faecalis KT11 against Some Pathogens and Antibiotic-Resistant Bacteria. Korean J. Food Sci. An., 38 (5):1064-1079. https://doi.org/10.5851/kosfa.2018.e40
Abdelsamei, H.M., Ibrahim, E.M.A., El-Sohaimy, S.A. \& Saad, M.A. (2015) Effect of storage on the activity of the bacteriocin extracted from Lactobacillus acidophilus. BVMJ, 28 (1): 216-222. http:// www.bvmj.bu.edu.eg

Abdeltwab, W.M., Abdelaliem, Y.F., Metry, W.A. \& Eldeghedy, M. (2019) Antimicrobial effect of chitosan and nano-chitosan against some pathogens and spoilage microorganisms. J. Adv. Lab. Res. Biol., 10 (1): 8-15. https://ejournal.sospublication.co.in

Acay, H., Yildirim, A., Güzel, E.E., Kaya, N. \& Baran, M.F. (2020). Evaluation and characterization of Pleurotus eryngii extract-loaded chitosan nanoparticles as antimicrobial agents against some human pathogens. Preparative Biochemistry \& Biotechnology, 1-10. https://doi.org/10.1080/10826068.2020.1765376

Adesina, I. A. \& Enerijiofi, K. E. (2016). Effect of pH and heat treatment on bacteriocin activity of Pediococcus pentosaceus IO1, Tetragenococcus halophilus PO9 and Lactobacillus cellobiosus BE1. SAU Sci-Tech. J., 1 (1): 113-118 https://www.researchgate.net/publication/321750303

Akbar, A., Sadiq, M.B., Ali, I., Anwar, M., Muhammad, N., Muhammad, J., Shafee, M., Ullah, S., Gul, Z., Qasim, S., Ahmad, S. \& Anal, A.K. (2019) Lactococcus lactis subsp. lactis isolated from fermented milk products and its 
antimicrobial potential. CYTA - Journal of Food, 17 (1): 214-220. https://doi.org/10.1080/19476337.2019.1575474

Ali, A.A. \& Toliba, A.O. (2018). Effect of organic calcium spraying and Nano Chitosan fruits coating on yield, fruit quality and storability of peach cv 'Early $\begin{array}{llllll}\text { swelling'. } \quad \text { Curr. } & \text { Sci. } & \text { Int., } & 7 & \text { (4): } & \text { 737-749. }\end{array}$ https://doi.org/10.13140/RG.2.2.30115.60965

Alishahi, A. (2014). Antibacterial effect of chitosan nanoparticle loaded with nisin for the prolonged effect. Journal of Food Safety, 34: 111-118 https://doi.org/10.1111/jfs. 12103

Azhar, N.S., Zin, N.H. \& Abdul Hamid, T.H.T. (2017). Lactococcus lactis Strain A5 Producing Nisin-like Bacteriocin Active against Gram Positive and Negative Bacteria. Tropical Life Sciences Research, 28 (2): 107-118. https://doi.org/10.21315/tlsr2017.28.2.8

Balouiri, M., Sadiki, M. \& Ibnsouda, S.K. (2016). Methods for in vitro evaluating antimicrobial activity: A review. Journal of Pharmaceutical Analysis, 6: 71-79. https://doi.org/10.1016/j.jpha.2015.11.005

Benkerroum, N., Oubel, H. \& Sandine, W.E. (2002). Effect of nisin on yogurt starter, and on growth and survival of Listeria monocytogenes during fermentation and storage of yogurt. Internet Journal of Food Safety, 1: 1-5. https://www.researchgate.net/publication/228885259

Bohrey, S., Chourasiya, V. \& Pandey, A. (2016). Polymeric nanoparticles containing diazepam: Preparation, optimization, characterization, in-vitro drug release and release kinetic study. Nano Convergence, 3 (3): 1-7. https://doi.org/10.1186/s40580-016-0061-2

Chawla, S.P., Kanatt, S.R. \& Sharma, A.K. (2014). Chitosan. Polysaccharides, Springer International Publishing Switzerland, 1-24. https://doi.org/10.1007/9783-319-03751-6 13-1

Correa-Pacheco, Z.N., Bautista-Baños, S., Hernández-López, M. \& CoronaRangel, M.L. (2018). Evaluation of Physical Properties and Antibacterial Activity of Bioactive Compounds-Loaded Chitosan Nanoparticles. Materials Science Forum, $\quad 936, \quad$ pp $\quad 3-7$ https://doi.org/10.4028/www.scientific.net/MSF.936.3

Divya, K. \& Jisha, M.S. (2018). Chitosan nanoparticles preparation and applications. Environ Chem Lett, 16:101-112. https://doi.org/10.1007/s10311017-0670-y

Divya, K., Vijayan, S., George, T.K. \& Jisha, M.S. (2017). Antimicrobia Properties of Chitosan Nanoparticles: Mode of Action and Factors Affecting Activity. Fibers and Polymers, 18 (2): 221-230. https://doi.org/10.1007/s12221017-6690-1

Duhan, J.S., Nehra, K., Gahlawat, S.K., Saharan, P. \& Surekha, D. (2013). Bacteriocins from Lactic Acid Bacteria. In: Biotechnology: Prospects and Applications. R.K. Salar et al. (eds.), Springer Singapore, pp: 127-142. https://doi.org/10.1007/978-81-322-1683-4 11

Eldaly, E.A., Mahmoud, A.F.A \& Abobakr, H.M. (2018). Preservative Effect of Chitosan Coating on Shelf Life and Sensory Properties of Chicken Fillets during $\begin{array}{lllll}\text { Chilled } & \text { Storage. } & \text { JNFS, } & 3 & \text { (3): }\end{array}$ https://www.researchgate.net/publication/326840681

Goraya, M.U., Ashraf, M., Ur-Rahman, S., Raza, A. \& Habib, A. (2013). Determination of Antibacterial Activity of Bacteriocins of Lactic Acid Producing Bacteria. Journal of Infection and Molecular Biology, 1 (1): 8-10 https://www.researchgate.net/publication/235754330

Kahdestani, S.A., Shahriari, M.H. \& Abdouss, M. (2021). Synthesis and characterization of chitosan nanoparticles containing teicoplanin using sol-gel. Polymer Bulletin, 78(2):1133-1148. https://doi.org/10.1007/s00289-020-03134-2 Kaktcham, P.M., Piame, L.T., Sileu, G.M.S., Kouam, E.M.F., Temgoua, J., Ngoufack, F.Z. \& Perez-Chabela, M.D. (2019). Bacteriocinogenic Lactococcus lactis subsp. lactis 3MT isolated from freshwater Nile Tilapia: isolation, safety traits, bacteriocin characterisation, and application for biopreservation in fish pâté. Archives of Microbiology, 201: 1249-1258. https://doi.org/10.1007/s00203019-01690-4

Khan, F., Yu, H. \& Kim, Y. (2020). Bactericidal Activity of Usnic Acid-Chitosan Nanoparticles against Persister Cells of Biofilm-Forming Pathogenic Bacteria. Mar. Drugs, 18 (270): 1-21. https://doi.org/10.3390/md18050270

Kim, S.G., Becattini, S., Moody, T.U., Shliaha, P.V., Littmann, E.R., Seok, R., Gjonbalaj, M., Eaton, V., Fontana, E., Amoretti, L., Wright, R., Caballero, S., Wang, Z.X., Jung, H., Morjaria, S.M., Leiner, I.M., Qin, W., Ramos, R.J.J.F., Cross, J.R., Narushima, S., Honda, K., Peled, J.U., Hendrickson, R.C., Taur, Y., van den Brink, M.R.M. \& Pamer, E.G. (2020). Microbiota-derived lantibiotic restores resistance against vancomycin-resistant Enterococcus. Nature, 572 (7771): 665-669. https://doi.org/10.1038/s41586-019-1501-z

Kravanja, G., Primožič, M., Knez, Ž. \& Leitgeb, M. (2019). Chitosan-Based (Nano) Materials for Novel Biomedical Applications. Molecules, 24 (1960): 123. https://doi.org/10.3390/molecules24101960

Kumari, K., Sharma, S. \& Kaundal, K. (2018). Production, Purification and Efficacy of Bacteriocin Isolated from Natural Lactic Acid Fermentation of Wild Himalayan Fig Fruit. Journal of Pure and Applied Microbiology, 12 (2): 879-885. https://doi.org/10.22207/JPAM.12.2.50

Le, N.T.T., Bach, L.G., Nguyen, D.C., Le, T.H.X., Pham, K.H., Nguyen, D.H. \& Thi, T.T.H. (2019). Evaluation of Factors Affecting Antimicrobial Activity of Bacteriocin from Lactobacillus plantarum Microencapsulated in Alginate-Gelatin
Capsules and Its Application on Pork Meat as a Bio-Preservative. Int. J. Environ. Res. Public Health, 16 (1017): 1-12. https://doi.org/10.3390/ijerph16061017

Lee, E.H., Khan, I. \& Oh, D. (2018). Evaluation of the efficacy of nisin-loaded chitosan nanoparticles against foodborne pathogens in orange juice. J. Food Sci. Technol., 55 (3):1127-1133. https://doi.org/10.1007/s13197-017-3028-3

Malinowska-Pañczyk, E., Staroszczyk, H., Gottfried, K., Ilona Kołodziejska, I. \& Wojtasz-Pająk, A. (2015). Antimicrobial properties of chitosan solutions, chitosan films and gelatin-chitosan films. Polimery, 60 (11-12): 735-741. https://doi.org/10.14314/polimery.2015.735

Meade, E., Slattery, M.A. \& Garvey, M. (2020). Bacteriocins, Potent Antimicrobial Peptides and the Fight against Multi Drug Resistant Species: Resistance Is Futile? Antibiotics, 9 (1): $32-50$ https://doi.org/10.3390/antibiotics9010032

Mokoena, M.P. (2017). Lactic Acid Bacteria and Their Bacteriocins: Classification, Biosynthesis and Applications against Uropathogens: A Mini$\begin{array}{lllll}\text { Review. } & \text { Molecules, } & 22 & \text { (8): } & 1255-1268 .\end{array}$ https://doi.org/10.3390/molecules22081255

Moreno, I., Lerayer, A.L.S., Baldini, V.L.S. and Leitão, M.F. de F. (2000) Characterization of bacteriocins produced by Lactococcus lactis strains. Brazilian Journal of Microbiology, 31:184-192. https://doi.org/10.1590/S1517$\underline{83822000000300007}$

Mostafa, G.A., Mokhtar, S.M., Eldeeb, G.S. \& Taha, R.A. (2015). Bacteriocins (From Bifidobacterium spp) Biopreservative Against Gram-Negative Pathogenic Bacteria in Minced Meat as a Critical Control Point. American Journal of Food Science and Nutrition, 2 (4): 55-67.

Mostafa, N.G., Gewaily, E.M., El-Zamik, F.I. \& Ali, A.S. (2019). Purification and specification of bacteriocin produced by some Lactobacillus spp. isolated from food. Zagazig J. Agric. Res., 46 (2): $489-500$ https://doi.org/10.21608/ZJAR.2019.33403

Namasivayam, S.K.R., Samrat, K., Debnath, S. \& Jayaprakash, C. (2015). Biocompatible chitosan nanoparticles incorporated bacteriocin (CSNps-B) preparation for the controlled release and improved anti-bacterial activity against food borne pathogenic bacteria Listeria monocytogenes. Res. J. Pharm. Biol. Chem. Sci., 6 (5): 625-631. https://www.researchgate.net/publication/283096124 Pan, C., Rezaei, H. \& Soor , A. (2011). Chitosan Disrupts Membrane Permeability of Lactic Acid Bacteria. Journal of Experimental Microbiology and Immunology (JEMI), 15: 7-14.

Prudêncio, C.V., dos Santos, M.T. \& Vanetti, M.C.D. (2015). Strategies for the use of bacteriocins in Gram-negative bacteria: relevance in food microbiology. J. Food Sci. Technol., 52 (9): 5408-5417. https://doi.org/10.1007/s13197-014-16662

Qi, L., Xu, Z., Jiang, X., Hu, C. \& Zou, X. (2004). Preparation and antibacterial activity of chitosan nanoparticles. Carbohydrate Research, 339: 2693-2700. https://doi.org/10.1016/j.carres.2004.09.007

Rabie, M.A., Abdelgaleel, A.A. \& Malcata, F.X. (2015). Proteolysis and Biogenic Amine Formation in Sterilized Edam-Type curd Slurry Inoculated with Probiotic Strains: Chemical Profile of Edam-Type Curd Slurry. Journal of Food Processing and Preservation, 39 (6): 2297-2303. https://doi.org/10.1111/jfpp.12475

Rizeq, B.R., Younes, N.N., Rasool, K. \& Nasrallah, G.K. (2019). Synthesis, Bioapplications, and Toxicity Evaluation of Chitosan-Based Nanoparticles. Int. J. Mol. Sci., 20 (22): 5776-5800. https://doi.org/10.3390/ijms20225776

Sidhu, P.K. \& Nehra, K. (2019). Bacteriocin-nanoconjugates as emerging compounds for enhancing antimicrobial activity of bacteriocins. Journal of King $\begin{array}{llll}\text { Saud University } & - & \text { Science, } & 31 \text { : }\end{array}$ https://doi.org/10.1016/j.jksus.2017.12.007

Singh, K., Mishra, A. \& Singh, A. (2018). Synthesis Characterization and In Vitro Release Study of Ciprofloxacin-Loaded Chitosan Nanoparticle. BioNanoSci., 8:229-236. https://doi.org/10.1007/s12668-017-0470-7

Tamara, F.R., Lin, C., Mi, F. \& Ho, Y. (2018). Antibacterial Effects of Chitosan/Cationic Peptide Nanoparticles. Nanomaterials, 8 (88): 1-15. https://doi.org/10.3390/nano8020088

Teixeira, M.C., Carbone, C., Sousa, M.C., Espina, M., Garcia, M.L., SanchezLopez, E. \& Souto, E.B. (2020). Nanomedicines for the Delivery of Antimicrobial Peptides (AMPs). Nanomaterials, 10: 560-583. https://doi.org/10.3390/nano10030560

Tenea, G.N. \& Suárez, J. (2020). Probiotic Potential and Technological Properties of Bacteriocinogenic Lactococcus lactis subsp. lactis UTNGt28 from a Native Amazonian Fruit as a Yogurt Starter Culture. Microorganisms, 8 (733): 1 13. https://doi.org/10.3390/microorganisms 8050733

Woraprayote, W., Malila, Y., Sorapukdee, S., Swetwiwathana, A., Benjakul, S. \& Visessanguan, W. (2016). Bacteriocins from lactic acid bacteria and their applications in meat and meat products. Meat Science, 120: 118-132. https://doi.org/10.1016/j.meatsci.2016.04.004

Wu, C., Wu, T., Fang, Z., Zheng, J., Xu, S., Chen, S., Hu, Y. \& Ye, X. (2016) Formation, characterization and release kinetics of chitosan $/ \gamma$-PGA encapsulated nisin nanoparticles. RSC Adv., 6: 46686-46695. https://doi.org/10.1039/C6RA06003J 
Yusuf, M.A. \& Abdul Hamid, T.H.A.T. (2013). Lactic Acid Bacteria: Bacteriocin Producer: A Mini Review. IOSR Journal of Pharmacy, 3 (4): 44-50. https://doi.org/10.9790/3013-034104450

Zacharof, M.P. \& Lovitt, R.W. (2012). Bacteriocins Produced by Lactic Acid Bacteria: A Review Article. APCBEE Procedia, 2: 50-56. https://doi.org/10.1016/j.apcbee.2012.06.010

Zaghloul, R.A., Abou-Aly, H.E., El-Housseiny, T.M., Ghonaimy, G.A. \& Ashry, N. M. (2015). Comparison of Antibacterial Activity of Fungal Chitosan and Some Preservatives Against Some Foodborne Pathogenic Bacteria. Egypt. J. Microbiol. 50: 31-42. https://doi.org/10.21608/EJM.2015.233

Zohri, M., Alavidjeh, M.S., Haririan, I., Ardestani, M.S., Ebrahimi, S.E.S., Sani, H.T. \& Sadjadi, S.A. (2010). A comparative study between the antibacterial effect of nisin and nisin-loaded chitosan/alginate nanoparticles on the growth of Staphylococcus aureus in raw and pasteurized milk samples. Probiotics Antimicrob. Proteins, 2: 258-266. https://doi.org/10.1007/s12602-010-9047-2

Zohri, M., Alavidjeh, M.S., Mirdamadi, S.S., Behmadi, H., Nasr, S.M.H., Gonbaki, S.E., Ardestani, M.S. \& Arabzadeh, A.J. (2013). Nisin_Loaded chitosan/alginate nanoparticles: a hopeful hybrid biopreservative. J. Food Saf., 33: 40-49. https://doi.org/10.1111/jfs.12021 